\title{
Replaying Empire: Racialized Violence, Insecure Frontiers, and Displaced Terror in Contemporary Video Games
}

\author{
David J. Leonard and C. Richard King \\ Washington State University
}

\begin{abstract}
In the wake of $9 / 11$, US popular culture has played an important role in the manufacture of consent and the mediation of contradictions. In particular, video games have afforded the production of interactive, narrative spaces for the reassertion of race, nation, and gender. Through a close reading of two video games, Gun and Ghost Recon Advanced Warfighter 2, we unpack the insecurities of empire and how racialized violence, colonial categories, and territorial claims work to resecure Whiteness, masculinity, and Americanness. Special attention is given to the militarization of video games and rhetorical struggles over the meaning of race and culture amid the 'War on Terror'.
\end{abstract}

The 'War onTerror' has made visible the desperate imaginings, disputed projects, and deadly networks anchoring the quickening of American empire. The various campaigns launched at home and abroad over the past five years have hinged upon the reiteration of national narratives, stories that celebrate the nation-state, legitimate its violence, and render its history in sanitized, if not mythological terms. Such stories at once reify and reproduce the entanglements of imperiled Whiteness, manifest destiny, and pathological others as they multiply and militarize the range of crisis zones and suspect people through a re-racialization of local and global relations (Denzin 2004; Giroux 2004; King 2008; Puar and Rai 2002; Winant 2008). Although the War on Terror may appear at first blush to be little more than the cynical calculus of imperial geopolitics, an intensification of the political economic cycles of global capital, or an example of a military state formation establishing hegemony in the service of these overlapping projects, culture, particularly media culture, has made this series of conflicts and crises possible, pleasurable, and powerful as sites for the application of force and fantasy, the fabrication of identity and experience, and the consolidation of meaning and community.

In many respects, through its news coverage, complicit creative projects, and largely conservative tone, US media culture has established its accepted understandings and ruling languages (Jackson 2005). Less appreciated has been the role of playful diversions in the War on Terror. Video games, as we argue throughout this essay, offer an instructive instance of the uses of pleasure to reiterate dominant ideologies about race, power, and terror within media culture and extend empire through its productions. According to the Entertainment Software Association, in 2007, video games have surpassed movies in terms of economic success $-\$ 18$ billion in total sales, half on software (Bangeman 2007). At the peak of US wars in Iraq and Afganistan, war-based video games were central to the video game market. In 2003, The New York Times, reported that 5 of 10 bestselling video games involved war or other types of violent conflict (Friedenberg 2003). Two video games, Gun and Ghost Recon Advanced Warfighter 2 (GRAW2), grant privileged access to the ideologies and imaginings that animate the articulation of racialization, play, and US imperialism at the start of the twenty-first century. In the United States alone, 1.2 million copies of GhostRecon Advanced Warfighter (GRAW) were sold, almost 900,000 for Xbox 360. Its popularity was matched with celebratory reviews and 'British Academy of Film and Television Arts Game of the Year Award'. Its sequel, Ghost Recon Advanced Warfighter 2 (GRAW2) netted 1 million in sales for its Xbox 360 edition. Like its predecessor, it also received widespread praise, winning 'Game of the Month' from Game Informer in May 2007. Similarly, as of October 2008, gamers had purchased 1.4 million units of Gun. Importantly, they allow readings of text and context, prompting a fuller understanding of the force of racial representation in a moment of imperial insecurity. On the one hand, we argue, set on the frontier and across the border respectively, they reiterate a set of colonial clichés about civilization and savagery, the necessity of 
violence, and the cultivation of White masculinity. On the other hand, despite visible opposition, corporate rhetoric, fan reception and social context extend the dehumanization of racial violence as well as the broader 'War on Terror'.

\section{Background}

Before examining the representational strategies deployed within Gun and GWAR2, it is important to highlight the powerful cooperative relationships that have developed between America's military, the video game industry, and the American colleges and universities. While war simulations are nothing new, nor are the ways in which the entertainment and academic industries serve the interest of the military industrial complex. Yet, in a post $9 / 11$ environment and given the technological advancements available in virtual reality, the power and presence of virtual warfare are immense.

Two things have occurred since $9 / 11$. One is that there has been an interesting trend in the kinds of games released, and the second thing is that $9 / 11$ is so culturally significant that the games take on new meaning (Barron \& Huntemann 2004).

Moreover, as noted by Nina Huntemann, the ubiquitous numbers of games and their immense popularity reflects the militarization of everyday life, which not only garners consent for the war on terrorism or the budget of the US military, but also has naturalized war as part and parcel of America in the twenty-first century. 'What I find really frightening is that in our playtime - in our leisure time, we're engaging in fictional conflicts that are based on a terrorist threat and never asking questions' (Barron \& Huntemann, 2004). Ed Halter, in From Sun Tzu to Xbox: War and Video Games, additionally notes the continuity of virtual warfare and 'ancient games that simulated war' (2006, p. xxvi), but sees a greater power in the realistic offerings of the video game industry.

Since $9 / 11$, commercial game designers are churning out a new generation of realistic games based on historical wars. Now gamers can go to their local mall, pick up a virtual reenactment of the Vietnam War, World War II, the Gulf war, or even something that approximates the current wars in Iraq and Afghanistan. (Halter 2006, p. xxvii)

While the military is using video games to both train and recruit (Harmon 2003; Slagle 2003; Turse, 2003; Halter 2006; Turse 2008; Huntemann and Payne 2009), the power of virtual warfare rests with its deployment and use of dominant narratives, tropes, and ideologies. Moreover, it rests with the teachings that take place via video games and its impact on its players. According to Dr. Tracy Alloway, war video games are important in training memory. 'I'm not saying they're good for your socialisation skills, but they do make you use your working memory,' she concluded. 'You're keeping track of past actions and mapping the actions you're going to take' (Alloway 2009). While writing about educational games, Rouner (2002) concluded that video games are effective instruments in facilitating behavioral or attitude change because of the narrative component of video game culture. Likewise, Peng's research on video games as a tool of nutritional change among adolescents pointed to similar qualities of video games:

People are so engaged in the narrative that they experience suspension of disbelief (i.e. they treat all the narratives as well embedded persuasive messages as if they were true) and they make little effort to counterargue because absorption and counterarguing are fundamentally incompatible (Peng 2009, p. 117).

Moreover, according to K.M Lee \& Peng (2006) and Lieberman (2006) 'computer game-based instruction has been shown to be effective in attention, and retention rate' (Peng 2009, pp. 116). Given the popularity of war video games within the United States, especially since 9/11, and as evidence in the current scholarship, which has concluded that video games are powerful in their ability to 'translate knowledge into behavior, in a trial-and-error way' (Peng 2006, p. 116) all while providing players a safe space 'to practice behavior change in a safe and entertaining way' (Peng 2006, p. 116), it 
is no wonder that the US military, along with its partners inside and outside the video game industry, have sought to use virtual reality as part of its military agenda.

Together, video game programmers/producers and the military have jointly constructed 'an arm of media culture geared toward preparing young Americans for armed conflict' (Turse 2003). For example, in 1997, the US Marine Corps formalized its relationship with Mäk Industries, inking a deal to develop the first combat simulation game jointly funded and developed by an entertainment company and the Department of Defense. Shortly thereafter, the US Army developed a deal with Mäk to create a sequel to their popular tank simulation game Spearhead which would be used at the US Army Center and School for training purposes.

While initially imagined as military training simulations, these cooperative relationships evolved to a point, it ultimately proved to be more dialectical, with 'the military has embraced entertainment titles at the same time the entertainment industry has embraced the military' (Turse 2003). While those initial jointly produced and created war games focused on training already enlisted military personnel, the second wave of games, those immensely popular within civilian populations, served as (1) source of profit for the video game industry, (2) vehicles of recruitment of future soldiers; and (3) an instrument of fostering support for US foreign policy and its increasing reliance on military prowess.

Leonard (2004) offers a helpful summary of the deepening entanglements between the US military and the video games. After initially recognizing the potential instructional use of Tom Clancy's Rainbow Six: Rogue Spear in simulated urban combat, Leonard notes:

In 2003, the Army developed its own tool of recruitment with America's Army, which was developed at the Naval Postgraduate School in consultation with Epic games and the THX division of Lucas films. Costing taxpayers upwards of eight million dollars, America's Army has been a huge success, with over 1.5 million registered users, bringing the training and operations of the military into millions of homes. The Defense Department has also worked closely with the production of games like Rainbow Six: Raven Shield and Socom II: U.S. Navy SEALs, utilizing each as a means to test and train military personnel, concerning leadership skills (Leonard 2004)

Embracing elements of military simulation trainers, 'squad leaders learn how to command nine soldiers in complex, confusing urban warfare scenarios. The game isn't about sprinting, Rambo-like, through alleys with guns blazing' (Slagle, 2003).

Another example of this powerful relationship is evident with Kuma Reality Games, a company that with the Defense Department and a team of military veterans, launched Kuma/War. The game, a first-person shooter, centers on actual military missions - a first in the industry. Kuma/War allows players to combat Al Qaeda and the Taliban as part of Operation Anaconda, or alternately, to enter Iraq theater in pursuit of important figures in the deposed regime. Simulated media coverage of the military missions intensifies their authenticity, producing a slippage between the seemingly discrete domains of war and popular culture. Similarly, Atomic Games has developed (to date it has not been published) a game entitled Six Days in Fallujah, which attempts to recreate and propel players into the actual battle that took place in Fallujah in April 2004 (Pauker, 2009).

Such games provide American teenagers and adults, regardless of race, class, gender, sexuality, and geography, an opportunity to join an imagined community of sorts with a principal purpose of defeating global terror. Describing the game Six Days in Fallujah, Juan Benito, the Creative Director at Atomic Games, captures the importance of these games:

......And that's a really important point because we recreate the events as factually and as accurately as we possibly can. And there will be a broad range of reactions and opinions on 
the experience itself. And for some, they may have fun. They may enjoy it. We are recreating and presenting these events and people, I think, will have their own individual reactions to it and those will be across the board. And that's what we want. We want people to experience something that's going to challenge them, that's going to make them think and provide an unprecedented level of insight into a great military significance (Otd. Nelson 2009).

Without leaving one's home, with minimal costs and no danger, these games provide civilian game players the chance to contribute to a national cause, to aid in our collective efforts to defeat the 'axis of evil.'

Allowing everyday citizens anywhere in the world to command a light infantry unit in Tajikistan, which it dubs 'a haven for terrorists and extremists,' Full Spectrum Warrior for Microsoft's X-Box system illustrates this deep play. Developed by personnel at the Army's Infantry School at Ft. Benning, Georgia; its importance rests with its ability to demonstrate the ways in which the military develops leaders (as a simulator it teaches important leadership skills) and with its imagination of war as an enterprise without injury, emotional distress, and death consequences. Likewise, this game focuses on the multifaceted dimensions of war, focusing on the heterogeneous nature of the modern US military. Ed Halter notes that the opening moments of Full Spectrum Warrior begin with a quote from General Krulak:

In one moment in time, our service members will be feeding and clothing displaced refugees providing humanitarian assistance. In the next moment, they will be holding two warring tribes apart - conducting peacekeeping operations. Finally, they will be fighting a highly lethal midintensity battle all on the same day. All within three city blocks. It will be what we call the three-block war (Otd in Halter 2006, p. 231).

This opening moment not only foreshadows the various types of missions that gamers will experience while playing this game, but provides a strong ideological narrative as to the role of the US military, one that is guided by a clear moral compass.

Collectively, these games, as well as others like Socom: Navy SEALs and Operation Desert Storm, enable its players to feel as if they were 'defending the country' (Napoli 2003), all while providing stability to the world, and in the process, we would argue, play out their fantasies and work through their anxieties. The cultural, political, and national significance of war video games rests not simply with their ability to simulate American war efforts, to assuage collective anxieties and fears, or the virtual ability 'to cause mass carnage on a grand scale ... through a carpet bombing' (Stallabras 1993), but in their ability to garner support, consent, and pride in the military and expanding contemporary military-industrial complex.

The production of war via video-games and the celebration of empire as a natural and necessary dimension of worldwide progress are not limited to the traditional wartime virtual playgrounds, but are equally evident in the reimagination of American historical conquest. Despite the already scant literature (Turse 2003; Leonard 2004; Halter 2006; Turse 2008; Huntemann and Payne 2009; King and Leonard 2009) focusing exclusively on foreign military encounters as the basis for discussing war games, we bring into focus imagined fronts in the 'War on Terror': the uneasy frontiers central to imperial campaigns against Indigenous peoples in Gun and a near future military intervention South of the border to squash Latin American insurgents in Ghost Recon Advanced Warfighter 2. We offer interpretive readings of how these games seize on these alternate theaters of terror and war, illustrating the powerful ways in which racial politics, empire building, and fear of the 'savage other' simultaneously guide the production and consumption of (virtual) warfare, racialized identities, and national narratives. 


\section{On the Frontier}

Shortly after the initiation of the Second Gulf War, an open letter to the people of Iraq encouraged the formation of a Bureau of Iraqi Affairs (Wasson 2003). It circulated widely on the internet, finding its ways into news outlets and electronic bulletin boards around the world. The ten point proposal juxtaposed the invasion of Iraq and the condition of Native Americans, parodying the manifest destiny powering the expansion of the 'War on Terror', while reminding readers of the force of American empire and its historical transgressions. Although this message went largely unnoticed by a broader public, military leaders and neo-conservative pundits were quick to reiterate a preferred American imperial idiom, 'Indian Country', to reframe Iraq, reinscribing it and the insurgency in terms of the racial policing of the insecure and hostile frontiers. Even as they waged a war of their own making, of and against terror, the military relied upon subdued visions of hostile 'Indians': while US forces fly Comanche helicopters into battle and launch Tomahawk missiles at enemy positions, commanders dub an important assault on insurgents, 'Operation Mayflower'. For its part, the mainstream media devoted much attention to a real American hero, Lori Ann Piestawa (Hopi), who sacrificed herself to protect civilization, particularly the life and honor of her (more famous and celebrated) EuroAmerican compatriot, Jessica Lynch (see Fields-Meyer 2005; Flannery \& Reid 2003).

In equally powerfulways, (imagined) Indians and Indianness fueled the 'WaronTerror' on the homefront as well. Immediately after 9/11, conservative Comanche commentator David Yeagley (2001) called for the creation and circulation of more images of the brave native warrior, especially American Indian mascots. More explosive, and ultimately reflective of the structure of feeling anchoring the war on terror, was the public panic over a polemic written by activist and scholar Ward Churchill (2001), who claims to be Cherokee and Creek. More than two years later, Churchill became the target of charges of un-American activities, for amongst other things dubbing those who died in the attacks 'little Eichmanns' complicit in an imperial and genocidal order. During the subsequent media firestorm, Churchill was attacked as a radical intellectual, hostile, divisive and dangerous. Politicians and pundits called for his firing from his tenured position in ethnic studies at the University of Colorado, questioning the quality and integrity of his scholarship, his lack of patriotism, his claims to Indianness, his politicization of knowledge, and his extreme incivility in a time of national emergency (King 2008).

In this context, the release of the video game Gun affords a powerful occasion to unpack the ideologies and imaginings energizing anti-Indian racism as well as US imperialism at the start of the twenty-first century. Although heralded by critics and enjoyed by countless gamers, unlike many video games, the targets of Gun voiced outrage at its depiction of Native Americans. Consequently, Gun allows readings of text and context, prompting a fuller understanding of the force of racial representation in a moment of imperial insecurity. On the one hand, we argue, set on the frontier and pivoting around the brutal adventures of Colton White, Gun reiterates a set of colonial clichés about civilization and savagery, the necessity of violence, and the cultivation of White masculinity. On the other hand, despite vocal resistance, both corporate rhetoric and fan reception blunted the impact of anti-racist interventions, extending the dehumanization of racial violence as well as the broader 'War on Terror'.

\section{Gun}

Activision released Gun in early 2006. With a tagline of 'experience the brutality, greed and lust that was the Wild West,' the video game broke with many other titles on the market, leaving beyond the commonplace virtual geographies of a gang-infested ghettocentric imagination, and the foreign theaters of war, to reimagine the 'Western Frontier.' In a world without laws or respect for life, Colton White, following the murder of his father, undertakes a journey in which he 'straddles the line between good and evil in a showdown against corrupt lawmen, a murderous preacher, renegade Army, psychopaths, merciless outlaws, and relentless warring tribes.' While the game's instructions highlight a myriad of evil doers, or individuals who provoke violence from the otherwise peaceful mountain man, Gun's narrative and visual representation make clear that savage-Indians (and 
animals as well) are the most violent, constant, and unabated threat to peace, democracy, and White masculinity. Importantly, because players play Colton, they simultaneously center the action and activate history, while defending civilization from wildness, treachery, and savagery.

The game's narrative and representational focus on the conquest of 'savage' indigenous populations and the goodness of European imperialism is established from the game's initial moments. Colton White's ancestors are travelling on horseback somewhere in the 'New World.' With one holding a cross in hand, it's clear that they are missionaries, spreading God's word throughout these 'savage lands.' As evident, the members of Coronado's Exposition, including Colton's relative, are viciously murdered by a group of Indian warriors, stereotypically imagined as savages who attack without cause or concern for human life. Even as the priest holds his cross up to the group of indigenous fighters, almost pleading for redemption and the sparing of his life (in some ways the scene reinterprets the crucifixion of Jesus), they beat and ultimately kill him, leaving the cross unattended on the land. Here, the game positions the white player/protagonist as the victims of unprovoked violence, inverting historical relations, while erasing contemporary connections and culpability.

The game jumps ahead three hundred years, where Ned White is seen teaching his son, Colton, the needed skills to survive the dangers presented by the frontier. At first honing gun and knife skills by killing buffalos as well as wolves and other threatening animals, proficiency and the death of his father forces Colton to confront the greatest threat of all: Apache Indians. The game's first mission takes Colton to Dodge City, where he is instructed to kill a group of Apache Indians, who are determined to destroy a bridge that leads the railroad through their land. The benevolence of the mission not only rests with Colton's bravery against the Apaches, taking on and killing many dozens of screaming Indians, who wildly run around, don stereotypical war paint and warrior garb, and use both tomahawks and arrowheads, some of which are on fire, but it also can be found in his determination to protect 'the Chinamen' and 'the coolies' who are building the bridge. Without Colton, their lives would be in jeopardy as would the future of the good, law-abiding settlers of Dodge City.

The game clearly imagines Native Americans as savage warriors, screaming throughout the game, as a sign of both an animal instinct and a determination to kill. Although, it should be mentioned that when Colton does take an Apache hostage, in preparation of execution, an Apache will say, in the calmest possible voice, "Let me go." Through the course of the game, Colton is instructed to not only slaughter (and yes this is the term used in the game), but to scalp those Apaches he has killed using a 'scalping knife' purchased at the local store. Moreover, during those missions where slaughtering Apaches constitutes the goal of the mission (you complete it and unlock achievements when all are killed), Colton can be heard expressing regret or outrage at letting some 'injuns' escape the only thing he can trust: his gun. The game's official strategy guide even makes light of the game's bloodshed and virtual re-enactment of genocide, describing one instance where Colton saves a few 'injuns' from a train as 'Karmic cleansing.'

In completing the mission by not only slaughtering Indians, but scalping them as well, Gun not only invokes the ubiquitous sincere fictions of Native American savagery and a benevolent American conquest that have long guided national mythology, but imagines the conquest as a site of masculine pleasure, for both Colton and the game's players, the game offers a powerful message regarding war and conquest. In another instance, Jenny, a prostitute, who provides guidance and sexual gratification to Colton, reminds him of the responsibility of a White masculine imperialistic project: to protect women and nation. She tells Colton as they prepare to travel through Apache lands, to "please promise me you'll put a bullet in my head before THEY ever have their way with me." Securing the uneasy borders of the frontier, here, not only reinforces racial, gendered, and sexual hierarchies, but it also clears a space for the allegorical story, where the Wild West stands in for the Middle East, a story about a 'new world order' imperiled by inhuman savagery that must be stopped for civilization 
to thrive on the frontier and closer to home.

\section{Electronic Activism}

Almost immediately after the release of Gun, Native American activists and their allies used the internet to launch an open challenge to the video game and its treatment of indigenous peoples. While online chatrooms and forums were abuzz with the heinousness of the new title, the Association for American Indian Development called for a boycott of Activision. Understanding the cultural work of play, they outlined a powerful critique. To begin, they noted that the game contained 'derogatory, harmful, and inaccurate depictions of American Indians,' even as the game and corporation appeared unaware of contemporary Native Americans, many of whom play video games. Worse, they asserted, Gun encouraged players to kill indigenous peoples, rewarding them for their violence and brutality, while silently reiterating genocidal actions against Native Nations. The anti-Indian racism central to the game, moreover, was according to the Association for American Indian Development, a sad commentary on the plight and struggle of indigenous peoples, precisely because Activision would not make a game in which 'African Americans, Irish, Mexicans, or Jews' were the targets of such grotesque racialized violence. In calling into question the content of Gun, online activists sought to cultivate a decolonial movement during an insecure imperial moment. Unfortunately, the prevailing cultural logic of post-civil rights America blunted their efforts, resulting in the reinforced legitimacy of national narratives and imperial ideologies.

\section{New Racism as Counter-Insurgency}

Despite the power challenge to colonial clichés marshaled in the call to boycott Activision, corporate rhetoric and public reaction worked to reinforce the contours of new racism, while quelling the insurgent critique of Gun.

On the one hand, Activision skillfully manipulated common sense understandings of racism and realism. In its official response to the protests, the gaming corporation stated:

Activision does not condone or advocate any of the atrocities that occurred in the American West during the 1800 s. GUN was designed to reflect the harshness of life on the American frontier at that time...It was not Activision's intention to offend any race or ethnic group with GUN, and we apologize to any who might have been offended by the game's depiction of historical events... (quoted in Gibson 2006).

The game is meant to be life-like and true, not politically correct. Moreover, Activision neither intended nor endorses anti-Indian racism. The apology, like so many other insincere and after-thefact, press releases, is meant to contain the problem, which is how overly sensitive people feel in this case, while letting the corporation off the hook. And by all accounts, the apology worked. Sales continued virtually unabated and Activision plans to release a sequel in the coming year.

On the other hand, gamers effectively policed the crisis as well. In online chatrooms and electronic forums, they invoked familiar strategies intent to erase the significance of racism and racialization, including charges of reverse racism and playing the race card and assertions meant to minimize or trivialize the critical reading of the game offered by the Association for American Indian Development and other activists. Typical of online comments were those posted by Funky: 'That'll teach Activision to make a game based on history. Now, let's fire up some lawsuits against EA for making those awful Medal of Honor game portraying Nazis as bad people' (Activision Racist shitstorm). Importantly, gamer discourse echoes the corporate commitment to the importance of historical realism and denial of the significance of racism - here glossed as absurdist, while comparing Indians with Nazis. 


\section{Across the Border}

The rhetoric of the 'War on Terror' has not only fed on the fantasies of the Old West, recoding the moral and racial boundaries embedded in the notion of the Frontier, but it has also projected its racialized theory of civilization and savagery into the future and across existing borders. Most notably, for the past few years, it has seized upon the purported threat of immigration from Mexico, the future demise of American civilization, and the dangers posed by unruly regimes in Latin America to identify the next theater in the 'War on Terror'. Indeed, White nationalists now routinely call for an end to the war in Iraq so that the troops can be positioned on the US-Mexico border. Such extreme rhetoric resonates harmoniously with more mainstream voices. To offer three recent and representative examples:

It's time to recognize that America's war on terror is being fought in places other than Iraq and Afghanistan. In fact, our most critical theater of war is being fought at the US-Mexico border. Our enemies are unlawful migrants who willfully violate our borders and thumb their noses at U.S. immigration laws......Most importantly, US national security is in serious jeopardy: Al-Quaida [sic] is known to regard the porous border with Mexico as an attractive venue for entering the country in order to kill thousands, if not millions, of US citizens (Lillpop, 2005).

[T]he FBI has received reports that individuals from countries with known al-Qaida [sic] connections have attempted to enter the U.S. illegally using alien smuggling rings and assuming Hispanic appearances. An FBI investigation into these reports continues (Rep. John Culberson quoted Dougherty 2006).

Our main concern is: Who's in our state? This is a critical issue today. They just arrested, down on the border, a couple of weeks ago, three al-Qaida [sic] members who came across from Mexico into the United States (Rep. Sue Myrick quoted in Dougherty 2006).

Such rhetoric has become commonplace in a post-9/11America, whereupon the discourse surrounding illegal immigration has flowed into the widespread calls for increased security and enhanced military operations as part of America's broader 'War on Terror'. Not surprisingly, Tom Clancy's Ghost Recon Advanced Warfighter 2 (GRAW2) entered into this discursive field, providing players (and American patriots) the opportunity to simultaneously work through hegemonically-induced fear and anxiety, and dominant understandings of the 'War on Terror' and the war on illegal immigration.

\section{Ghost Recon Advanced Warfighter 2}

GRAW 2 continues were GRAW ended, a game which concluded with Captain Mitchell (the protagonist and player-controlled character) successfully saving the United States' President, who had been captured by Mexican rebels, inside Mexico City and in doing so defeated a dangerous terrorist cell flourishing right across the US border. Only twenty-four hours removed from this monumental victory, Captain Mitchell is called back to duty after American Intelligence operatives detected activity from the terrorist rebels, who are believed to be planning a retaliatory nuclear attack on the United States within seventy-two hours. While replicating commonly circulated narratives of terrorists getting their hands on nuclear weapons and US heroes having the immediate power to thwart their evil attempts (see Fox's 24), GRAW2 imagines this scenario through a particular geographic imagination: a virtually constructed battle on the US-Mexico border.

While in many ways reinscribing and deploying the hegemonic tropes and aesthetics available within practices of virtual warfare - brave White male soldier battling evil; violence without evidence of death or destruction; hyperpatriotism; and a racialized enemy - the power of GRAW2 rests with its politics, specifically its effort to further spotlight Latin America as the next and most important theater in the 'War on Terror'. For example, GRAW2 doesn't simply offer players the opportunity to thwart a rebel insurrection lead by Mexican terrorists (who appear to be imagined as anti-American, anti-globalization fanatics), but provides a narrative in which Captain Mitchell - the lone White savior - 
protects El Paso from a Mexican invasion. Amid a broader discourse that continually describes illegal immigration as part of a Mexican effort to reconquer the Southwest (King 2007), the representational field and narrative offerings of GRAW2 are especially powerful. Moreover, the game represents the border in harmony with prevailing imagery as a barren wasteland, an open frontier devoid of civilization, and more significantly the portal through which illegals presumably flow into the United States every day. Moreover, the game imagines Juarez as a lawless city, marked by drugs, prostitution, and crime, yet oddly lacking civilians. Most importantly, the narrative of GRAW2 chronicles the efforts of Mexican rebels (terrorists) along with their Latin American allies to expel US influence within its national borders alongside anti-US movements in Panama, Brazil, and throughout Latin America. Replicating recent news coverage that paints Latin America (Using Hugo Chavez and Fidel Castro as the most visible symbols) as anti-US, as radical threats to US power and global stability, GRAW2 provides a visual reminder of the localized threats within the Western Hemisphere. In linking these anti-colonial and anti-US (imperialist) movements to a US global war on terror GRAW2 offers a powerful reimagination of the geo-political moment, one that homogenizes all who defy US global power, who call for self-determination within their borders, or who question the efficacy of global capitalism within the Third World, depicting them as part of an axis of evil that requires attention within a successful 'War on Terror'. The imaginings of the next front in the war on terror animating GRAW2 pivot around moralized and racialized rhetorics that blur stereotypes of Latina/o immigrants, cultural difference, barbarism, oppositional politics, policy alternatives, and anti-Americanism together to create a dangerous threat demanding military intervention.

GRAW2, then, inscribes an overt racial text that interweaves accepted understandings of illegal immigration and an imperiled America to recast terror and terrorists as alien, abject, and monstrous. Throughout the game, the Mexican rebels are constructed in absence of a story, instead seen as faceless (and history less) rebels, marked only by their use of Spanish. Rendered as different, foreign and inaccessible (no translation of Spanish used by rebels; Mexican loyalists of course speak English), the game's narrative is through the eyes and narrative of the US military. In juxtaposition to the faceless Mexicans, who are marked by their Spanish accents and their presumed hatred of America, the 'Ghosts' aptly named, are (ironically) a multiracial bunch who are led by Captain Mitchell, the classic White hero, whose intelligence, courage, and masculine qualities prove to be the prefect remedy for the evils plots of these Mexican terrorists. While his 'band of brothers' is named 'ghosts' because their presence within Mexico is unconfirmed and without official sanction of the US government, this nomenclature captures that inscribed whiteness of Mitchell, the US military, and the American empire. 'Ghosts' offer the perfect metaphor for whiteness, which despite extensive critique by activists and academics alike, remains invisible, unmarked, unnamed, the norm. The explicit efforts to racialize, dehumanize, dehistoricize, and demonize Latina/os in GRAW2 work in unison with the whitened (White American) space of identification it opens for the player as Mitchell. Importantly, in a militarized and imperial cultural space anchored in securing and celebrating whiteness, this space of identification enables an interactive narrative that quite implicitly uses alien and racialized others, hostile to capital, the rule of law, and the mores of civilization to advance an argument for the defense of White supremacy in the twenty-first century.

\section{International Politics of Gaming}

Although unheard by most gamers, an increasingly vocal critic of the Ghost Recon franchise has crystallized around the globe. In 2004, the North Korean government denounced Ghost Recon 2 for its negative representation of its people, history, and government. Two years later, Gabriella Ramirez, a Venezuelan legislator, condemned Mercenaries 2: World in Flames and its producer, Pandemic studios, for its pernicious representation of Venezuela and its 'justification for an imperialism aggression' (Surette, 2007). Most recently and following the release of GRAW2, Héctor Murguía Lardizábal called upon Mexican authorities to prevent the invasion of US culture by stopping GRAW 2 from getting into the hands of children. He described the game as 'a criminal act against the intellectual capacity of 
the people of Juarez,' painting 'a negative picture of his city' and 'encouraging tensions between the US and Mexico' (Surette, 2007). Heeding these calls, Governor Jose Reyes Baeza Terraces ordered the seizure of all copies of GRAW2 within the state of Chihuahua. Read against efforts to US politicians to legislate against video game violence and sexual content, online discussants seized upon this opportunity to not only lend support to Ubisoft (the French-based producer of the game) and the game itself, but to deploy commonly-held beliefs about Mexico, and immigration into the United States. On GamePolitics.com numerous posters validated the game's offering, because in their estimation Juarez was 'a shithole, where violent crime was rampant.' However, one poster especially captured the level of animosity in the discussion, and its links to a broader anti-immigrant sentiment when he reminded the Governor of the following: 'Shut up Jose and just make sure my lawn was done right' (Newspaper Report 2007). As evident here, the links between race, GRAW2, and the hegemonic discourse concerning illegal immigration have quite a profound place inside and beyond this specific game, simultaneously playing off the anxieties of American audiences, advancing an active defense of White power, unsettling those communities it targets, and ultimately containing efforts to challenge the common sense anchoring it.

\section{Conclusions}

In the wake of $9 / 11$, the United States has returned to national narratives that offer certainty, comfort, and security. It has not returned to them without change or complication however. In fact, as this brief discussion of Gun and GWAR2 documents, the rendering of US imperialism increasingly hinges on established understandings of racial difference as well as emergent ideologies. In particular, as our interpretation underscores, the production and reception of Gun and GWAR2 demand the reiteration of colonial clichés and the assertion of new racism to work in a post-9/11 context. Importantly, returning to the Wild West and crossing the border in the near future is not so much an escape from the Middle East as an affirmation of the entanglements of terror and territory anchoring it, re-territorializing the global war on terror and the moral standing of its racialized participants through play.

Indeed, this essay suggests an important avenue for future research: as countless bodies fall injured and dying, shattering families and communities over here and over there, and multinational corporations profit on increased militarism, diminishing natural resources, and public panics, many in the United States seek refuge in fantasy worlds of virtual play. Offering a more interactive cultural medium that provides players with new scenarios, locales, and places of play weekly, virtual reality has taken the lead in terms of providing a sense of security and power otherwise unavailable in this currently unstable moment. Significantly, as our account of Gun and GWAR2 illustrates, these lucid spaces are not all fun and games, but deadly serious reiterations of the networks of power and the ideologies of difference that drive so called 'War on Terror' and less recognized campaigns against communities of color closer to home. We hope subsequent scholarship will take seriously video games set during the Vietnam War like Vietnam Purple Haze and Shellshock Nam, and those depicting the war on crime in urban America, including Grand Theft Auto: San Andreas and True Crimes: Streets of $L A / N Y$, focusing on the interconnectedness of militarism, policing, and racialized violence within virtual reality (and those connected discursive fields and institutional formations). Such endeavors, we believe, will detail the ways in which video games, as exemplified here by Gun and GWAR2, turn on dehumanizing racialized violence directed at bodies of color, pivot around a rhetoric of danger on insecure frontiers, and encourage a reworking of the contours of fear and victimization so that white consumers can occupy them, even when communities of color challenge the signifying practices and social privilege at the heart of dominant force fields.

\section{References}

--- (2006, February 3). Activision Racist Shitstorm: Full report; Publisher fights to save scalp. [Online]. (Retrieved September 30, 2006). (URL Spong Web Site: http://news.spong.com/article/9620?cb=266) 
Bangeman, E. (2008, January 24). Growth of Gaming in 2007 far Outpaces Movies, Music. [Online]. (Retrieved September 8, 2009) (URL Ars Technia Web Site at: http://arstechnica.com/gaming/news/2008/o1/growth-ofgaming-in-2007-far-outpaces-movies-music.ars)

Barron, M., and Huntemann, N. (2004). Militarism \& video games: An Interview with Nina Huntemann. [Online]. (Retrieved January 8, 2005). (URL: http://www.mediaed.org/news/articles/militarism). Boston: Media Education Foundation.

Churchill, W. (2001). Some People Push Back: On the Justice of Roosting Chickens. [Online]. (Retrieved 15 June 2003). (URL http://www.ratical.org/ratville/CAH/WCog1201.html)

Denzin, N.K. (2004). The War on Culture, the War on Truth. Cultural Studies <=>Critical Methodologies, 4(2), pp. 137-142.

Dougherty, J. (2006, November 16). Lawmaker: Terror War Spilling across the Border. [Online]. (Retrieved April 7, 2007). (URL WorldNetDaily Web Site: http://www.worldnetdaily.com/news/article.asp?ARTICLE_ ID=47401)

Fields-Meyer, T. (2005). Jessica Lynch's Gift. [Online]. (Retrieved September 2, 2009).(URL People Web Site: http://www.people.com/people/archive/article/o,,20147704,00.html.)

Flannery, P. \& Reid, B. (2003). Profile: Lori Piestewa. [Online]. (Retrieved September 2, 2009). (URL Arizona Republic Web Site: :http://www.azcentral.com/news/specials/veterans/articles/piestewa-2.html)

Friedenberg, M. (2003, April 3). War Video Games Remain Popular as Real Battles Rage.[Online]. (Retrieved September 8, 2009).(URL New York Times Web Site: http://www.nytimes.com/uwire/uwire_ ETXD040320032392494.html?eX=1127278800 )

Gibson, E. (2002, February 2). Activision responds to accusations of racism. [Online].(Retrieved September 30, 2006). (URL Game Industry.Biz Web Site: http://www.gamesindustry.biz/content_page.php?aid=14446)

Giroux, H. (2004). War on Terror: The Militarising of Public Space and Culture in the United States. Third Text. 18(4), pp. 211-221.

Halter, E. (2006). From Sun Tzu to Xbox: War and Video Games. New York: Thunder's Mouth Press.

Harmon, A. (2003, April 3). More than Just a Game, But How Close to Reality. [Online]. (Retrieved July 8 , 2003). (URL New York Times Web Site: http://www.nytimes.com/2003/04/03/technology/circuits/o3camp. html)

Huntemann, N.B. \& Payne, M.T. eds. (2009). Joystick Soldiers: The Politics of Play in Military Video Games. New York: Routledge.

Jackson, R. (2005). Writing the War on Terrorism: Language, Politics, and Counter-Terrorism. Manchester: Manchester University Press.

King, C. R. (2009). Fear of a Brown Nation: Invasion, Reconquest, Aztlan and Other White Supremacist Anxieties. Manuscript in preparation.

King, C. R. (2008). Some Academics Try to Push Back: Ward Churchill, the War on Truth, and the Improbabilities of Interruption. Cultural Studies<=>Critical Methodologies, 8(3).

King, C.R., and Leonard, D.J. (2009). War Games as a New Frontier: Securing American Empire in Virtual Space. In: Huntemann. N. B. \& Payne, M. T., eds. (2009). pp. 91-105). 
Lee, K. M. \& Peng, W. (2006). A brief biography of computer game studies. In Vorderer, P. and Bryant, J. eds,(2006), pp. 325-345.

Leonard, D. (2004). Unsettling the military entertainment complex: Video games and a pedagogy of peace. Studies in Media \& Information Literacy Education, p.4.

Lieberman, D.A. (2006). What we can learn from playing interactive video games. In Vorderer, P. and Bryant, J. eds. (2006), pp. 379-398.

Lillpop, J.W. (2005, December 31). War on Terror Begins on the U.S.-Mexico Border. [Online]. (Retrieved April 7, 2007). (URL American Daily Web Site: http://www.americandaily.com/article/10979)

... (2009, September 7). Memory Prowess Linked to Gaming. [Online]. (Retrieved September 8, 2009). (URL BBCWebsite: http://news.bbc.co.uk/2/hi/uk_news/scotland/tayside_and_central/8241348.stm)

Napoli, L. (2003, March 27). War by Other Means. New York Times, Section G, p. 1

Nelson, R. (2009, April 13). Joystiq interview: Six Days in Fallujah. [Online]. (Retrieved September 8, 2009). (URL Joystiq Web Site: http://www.joystiq.com/2009/04/13/joystiq-interview-six-days-in-fallujah/)

--- Newspaper Report: Mexican State Govt. Will Seize All Copies of GRAW. [Online]. (Retrieved March 26, 2007). (URL GamePolitics Web site: http://gamepolitics.com/2007/03/23/mexican-government-to-confiscateall-copies-of-graw2/)

Peng, W. (2009). Design and evaluation of a computer game to promote a healthy diet for young adults Health Communication. 24( 2), p. 116.

Puar, J.K. \& Rai, A. S. (2002). Monster, Terrorist, Fag: The War on Terrorism and the Production of Docile Patriots. Social Text 72, pp. 117-148.

Slagle, M. (2003, October 14). Military Recruits Video Games as Training Aid. [Online]. (Retrieved March 26, 2004). (URL Contra Costa Times Web Site: http://www.contracostatimes.com/mld/cctimes/business/7009332. htm?1c)

Stallabras, J. (1993, March/April). Just gaming: allegory and economy in computer games. New Left Review 198, pp. 83-106.

Surette, T. (2007, March 9). Mexican Mayor Slams GRAW2. [Online]. (Retrieved March 26, 2007). (URL GameSpot Web Site: http://www.gamespot.com/news/6167149.html)

---. (N.D.) The Trouble with War Games. [Online]. (Retrieved September 8, 2009). (URL Intelligent Life Web Site: http://www.moreintelligentlife.com/story/6-days-fallujah)

Turse, N. (2008). The Complex: How the Military Invades Our Everyday Lives. New York: Metropolitan Books.

Turse, N. (2003). The Pentagon invades your Xbox. [Online]. (Retrieved March 27, 2003). (URL Znet Web Site: http://www.zmag.org/content/showarticle.cfm?SectionID=51\&/temID=4688)

Vorderer, P. and Bryant, J. eds.(2006) Playing computer Games: Motives, responses, and Consequences. Mahwah, N.J.: Lawrence Erlbaum Associates, Inc.

Wasson, G. (2003). Letter To Iraqis From the Bureau of Indian Affairs. [Online]. (Retrieved June 15, 2003). (URL Dissident Voice Web Sitet: http://dissidentvoice.org/Articles4/Wasson_BIA.htm.)

Winant, H. (2004). The New Politics of Race: Globalism, Difference, Justice. Minneapolis: University of Minnesota Press. 
Yeagley, D. (2001). Make More Indian Warrior Images. Grand Forks Herald 2 Dec. [Online]. (Retrieved Sept 3, 2009). (URL Blue Corn Comics Web Site at: http://www.bluecorncomics.com/stype1c2.htm) 